\title{
TTR
}

Traduction, terminologie, rédaction

\section{Rewrapping Indianness for Spain: The Peritextual Representation of Native North American Identity in Literary Translations}

\section{Isis Herrero López}

Volume 28, numéro 1-2, 1er semestre-2e semestre 2015

Territoires, histoires, mémoires

Territories, histories, memories

URI : https://id.erudit.org/iderudit/1041649ar

DOI : https://doi.org/10.7202/1041649ar

Aller au sommaire du numéro

Éditeur(s)

Association canadienne de traductologie

ISSN

0835-8443 (imprimé)

1708-2188 (numérique)

Découvrir la revue

Citer cet article

Herrero López, I. (2015). Rewrapping Indianness for Spain: The Peritextual Representation of Native North American Identity in Literary Translations. TTR, 28(1-2), 39-64. https://doi.org/10.7202/1041649ar
Résumé de l'article

Quand la littérature est traduite et publiée dans un nouveau marché cible, les éléments péritextuels des livres sont souvent modifiés et actualisés pour des raisons commerciales et esthétiques. Si la traduction implique des identités très différentes decelle de la culture cible, les péritextes offrent une grande quantité d'information sur les représentations ethniques qui sont acceptées et habituelles relativement aux identités de la culture source et de ses membres. Notre article analyse cette situation au regard des traductions espagnoles des littératures écrites amérindiennes. L'examen des péritextes des traductions disponibles en Espagne permet d'établir si les maisons d'édition partagent une image commune des Amérindiens, de déterminer comment cette image s'utilise d'un point de vue linguistique et visuel, et d'évaluer les conséquences de cette représentation culturelle. L'article comprend une discussion sur la convergence de la traductologie, des études amérindiennes et de l'imagologie pour étudier ces traductions et souligne l'importance d'utiliser une perspective multidisciplinaire. 


\title{
Rewrapping Indianness for Spain: The Peritextual Representation of Native North American Identity in Literary Translations ${ }^{1}$
}

\author{
Isis Herrero López \\ Independent Scholar
}

\begin{abstract}
When literature gets translated and published in the target market, the peritextual elements of the books get modified and updated because of commercial and aesthetic issues. If the translation involves identities very different from that of the target culture, then the peritexts offer a great amount of information about the ethnic representations that are accepted, welcome and customary as for the identities of the source culture and its members. This paper analyzes such a situation in relation to the Spanish translations of Native American written literature. By means of examining the peritexts of the available renditions in Spain, it is possible to establish if the publishing houses share a common image of Indianness, how it and its alternatives are used linguistically and visually, and what are the consequences of those cultural representations. This paper also includes a revision of the convergence of Translation Studies, Native American Studies and Imagology Studies in researching these renditions, and it stresses the importance of using this multidisciplinary point of view on the research materials.
\end{abstract}

Keywords: Native American literatures, ethnic representations, peritexts, literary translation

\section{Résumé}

Quand la littérature est traduite et publiée dans un nouveau marché cible, les éléments péritextuels des livres sont souvent modifiés et actualisés pour des raisons commerciales et esthétiques. Si la traduction implique des identités très différentes decelle de la culture cible, les péritextes off rent une grande quantité d'information sur les représentations ethniques qui sont acceptées et habituelles relativement aux identités de la culture source et de ses membres. Notre article analyse cette situation au regard des traductions espagnoles des

1. Pour cet article, l'auteure a reçu le prix Vinay et Darbelnet, décerné par l'Association canadienne de traductologie [NDLR]. 
littératures écrites amérindiennes. L'examen des péritextes des traductions disponibles en Espagne permet d'établir si les maisons d'édition partagent une image commune des Amérindiens, de déterminer comment cette image s'utilise d'un point de vue linguistique et visuel, et d'évaluer les conséquences de cette représentation culturelle. Larticle comprend une discussion sur la convergence de la traductologie, des études amérindiennes et de l'imagologie pour étudier ces traductions et souligne l'importance d'utiliser une perspective multidisciplinaire.

Mots-clés : littératures amérindiennes, representations ethniques, péritextes, traduction littéraire

\section{Introduction}

When discussing, in 1995, with William Bevis his new ideas for what would become The Heartsong of Charging Elk (2000), James Welch mentioned that he found interesting "how [he] would write this book and then how would it be translated into French and how French people would react to this" (Bevis, 1995, n.p.). Interesting as this may be (after all, the French translation of The Heartsong of Charging Elk was published only one year after the original English text), the truth is that Native American literatures have only seldom been an object of study from the perspective of translation. ${ }^{2}$ Most of the research carried out in this respect deals with English transcriptions of oral literature (see Krupat, 2002; Swann, 2011), and with the processes of translation done by North American Indian authors themselves when writing in English (see Carbonara, 2009; Krupat, 2000). However, translation of Native American written literature into any language other than English is a neglected area of study, with few projects focusing on this broad issue. $^{3}$

This unexplored area is my focus, because, in the 1970s and 1980s, against a backdrop of little expectation, the Spanish market received the first translations of books authored by North

2. The expression "Native American literatures" refers to both oral and written productions by authors considered North American Indians according to the cultural and legal definitions of the indigenous tribes of the United States. The article focuses exclusively on the United States and its indigenous people, artificial as this division between Native American tribes and First Nations may be. Due to this focus, the widely accepted terms "Native American" and "Indian" are used interchangeably.

3. Horáčková (2010) studied translations into Czech, and I studied translations into Spanish (Herrero López, 2013). 
American Indian writers. ${ }^{4}$ The present paper analyses the peritexts of 47 translations into Spanish and describes how Indianness is (re)constructed in the rewrapping of these renditions to promote them to Spanish audiences. Here, "Indianness" refers to the discursive construct of the identity of Native Americans used in non-specialized contexts. Since this paper focuses on this construct, the North American Indian identity is referred to in the singular, although I am fully aware of the diversity of Indian identities existing in the individual indigenous communities, in the Native grouping, and in the different legal, social and cultural dimensions of North American Indian lives.

In the first section of the article, I will examine the theoretical connections of my research, not only with Translation Studies, but also with Native American Studies and Imagology Studies. After presenting my approach, the specific case of Spanish translations will be addressed, as I will describe the different kinds of peritexts according to their thematic and editorial characteristics. Finally, conclusions will be drawn concerning the general patterns shared by most of the publications, as well as the exceptions observed in the descriptive part.

\section{Indianness: At the Crossroads of Disciplines}

The present paper is placed at the crossroads of three disciplines, namely Native American Studies, Translation Studies and Imagology Studies. Such a complex perspective offers multiple benefits, for it incorporates points of interest shared by the three disciplines (i.e., the production of cultural images of the Other), as well as concerns deeply ingrained in each of the three areas of research (i.e., the interpretation of Indian issues by nonIndians, the question of culture and power asymmetries, and the combination of text and context with discursive practices). The conjunction of these elements allows the study of the translation of Native American literature into Spanish to be put under a series of spotlights that both illuminate and clarify some minute but important details of the internationalization of Indianness, details that bring out the discursive construct as a consumable product in

4. In this paper, I consider "North American Indian writers" as individuals formally engaged in a Native American community as well as those consultants whose words were translated and recorded in English by white scribes and interviewers-for example, Black Elk, whose stories were written down by John G. Neihardt (1932). 
a new scenario of cultural, social and historical circumstances still to be critically analyzed and interpreted.

In this paper, the interest of Native American Studies for the Indian perspectives on history, ethnography, identity, sociopolitics, and literature is accentuated by its combination with Translation Studies and Imagology Studies. Since “Native American' literature is at the forefront of the humanities component of Native American studies" (Thornton, 1998, p. 95), its dissemination beyond the national boundaries of the United States is directly linked with questions of native identity, aesthetics, and authorship. The study, from a translation perspective, of the dynamic constitution of identities (Robyns, 1994, p. 405) as well as their derived (mis)representation, appropriation and authentication allows us to understand the commodification of North American Indians beyond the borders of the United States, particularly when it concerns directly the art produced by the Indian tribes themselves.

Since "international interest in Native Americans [is not] unusual" (Bataille, 2001, p. 1), it is relevant and necessary to pay attention to the intercultural contextualization of the Indian identity in the contemporary global culture of consumption. It should be remembered, firstly, that the reception of the text, author or movement and its interpretation by the target audience "is shaped less decisively by its intrinsic qualities than by the cultural and social identities of its readers, the varying assumptions and expectations, interests and abilities they bring to their interaction with the text" (Venuti, 2008, p. 28). Secondly, it is necessary to take into account that, when encountering the Other and their identity, "the primary referent is not to empirical reality, but to an intertext, a sounding-board, of other related textual instances" (Leerssen, 2007, p. 26). As any community always has a specific cultural and social (hi)story in relation to the Other, and possesses both new and old information on their identity, the political and cultural expectations become materialized in "value judgments, prejudices, conventions, habits, traditions, political and power relationships" (KuranBürçoğlu, 2000, p. 144), turning the abstract conceptualization of the Other into a tangible representation by means of discourses, intertextuality and imagological strategies.

The presence of the Other in a new context may end in two different and opposite attitudes in the receiving culture: it may induce a reformation in the vision of the foreign and the strange, 
thanks to some innovative characteristics, but "it too may harden into a cultural stereotype" of the Other (Venuti, 1998, p. 75). Both Translation Studies and Imagology Studies are concerned with this situation and take into account the circumstances that may bring about the two attitudes just mentioned. As a consequence, the study of North American Indian literary productions will benefit greatly from these perspectives, since the identitarian representation of the Other, as "textual tropes rather than sociological or anthropological data" (Leerseen, 2007, p. 27), are placed, through translation, into a new consumption and commercial system outside the United States-inside Spain in the case of this particular paper.

In order to study the representation of Native American identity in the translations into Spanish of the literature by Indians themselves, not all the elements that form the paratext are studied. The focus is placed on the peritexts, the elements that share the same physical space as the book, that closely surround the text (Genette, 1997, pp. 4-5). Focusing on peritexts when investigating Spanish representations of North American Indians is justified by the fact that they are almost always the first component of the book that potential and actual readers encounter prior to starting to read (Rättyä, 2001, p. 179), making them the ideal place for marketing the contents of the text as well as the poetics of the culture of reception. In addition, the translated peritexts, as promotional devices, are characterized by being "often controlled by institutional agents such as publishers, editors and reviewers" (Summers, 2013, p. 13), not by the authors and their intentionality.

The evaluation of the Spanish versions of works by Native Americans in the present paper will point out if the (re)constructions and representations of the Other match "the traditional image of their country and culture" (Soenen, 1995, p. 19) in the receiving context or if, on the contrary, they are contributing to the growth of an audience willing to know about real, contemporary Native Americans, just as Bevis (1995, n.p.) believed Welch's books did.

\section{Translated Peritexts and the Construction of Identity}

In Spain, the market has incorporated 47 translations of books authored by Native Americans, as well as 29 reprints (19752014). All these publications have few features in common, a reality that offers important data about the whole process of selecting and receiving this kind of literature in Spain. Besides 
being all prose writings, the renditions have been published in the context of broad and catch-all series, without thematic, generic or cultural ties among the different authors and texts included in the collections. This same lack of a specialized milieu is found at the level of the publishing houses: none of the 17 imprints that have ever put a North American Indian work into the market has established itself as the reference model for the other publishing houses in the country. Such a circumstance is the result both of random selections of books, according to the changing interests of the target market, and of the historical particularities of some publishing houses as well as some authors' productions. Thus, for instance, the publication of Vine Deloria's El general Custer murió por vuestros pecados: un manifiesto indio [Custer Died For Your Sins: An Indian Manifesto], a political essay on Indian issues, was brought about by the political interests of the Spanish audience at the end of Franco's dictatorship. On the other hand, the publishing house Tusquets stopped its translation of the Louise Erdrich tetralogy (focused on North Dakota fictional Anishinaabes living on and off the reservation) because it went through a difficult economic period in the mid-1990s (Proyecto Filosofía en español, 2012, n.p.). Finally, some of the best-known Indian authors-Leslie Marmon Silko, James Welch, Janet Campbell Hale and D'Arcy McNickle, among many others- have never been translated because Spanish interest in Indian writers did not emerge until the 1990s, whereas the so-called Native American Renaissance started in the 1970s.

In order to understand the existence of such a heterogeneous corpus, it is necessary to study the translation process and the marketing of these renditions, paying particular attention to the labor of all the translation agents involved in these editorial activities. The present paper examines, in particular, the role of Indianness in the promotion of the renditions in Spain, and the spread of it among the different publishing houses in the country. For this, two main questions about the peritexts of the Spanish translations of Native American literature are used: (1) Which are the most and least frequent representations of Indianness in Spain? (2) How have those representations been expressed in both textual and non-textual discourses?

The present study queries the importance of the context in the (re)creation of Indianness, for such identity is usually defined "in specific historical and institutional sites within the specific 
discursive formations and practices, by specific enunciated strategies [...] [and] within the play of specific modalities of power" (Hall, 1996, p. 4). The identitarian meaning produced by the surrounding circumstances is accumulated through the years because of the movements of the literary texts and their identity representations between and within the different literary systems (Venuti, 2008, p. 37). This means that the "intercultural confrontation" (Leerssen, 1991, p. 129) of what represents the Self and what stands for the Other depends, to a large extent, on the particular background knowledge of the culture of reception.

In Spain, the current perceptions of the indigenous peoples of the United States are directly connected with the small interest in Native Americans that Spaniards have had in comparison with, for example, the popular Indian hobbyist movement in Germany and elsewhere in Northern and Western Europe (see Taylor, 1988; Kalshoven, 2012). Spanish readers have always been imperceptibly influenced by the historical connection of the country with Central and South America: the anti-Spanish Black Legend, the defense of the Indians by Bartolomé de Las Casas, and the debate between the representation of Native peoples as soulless and unhuman beings on one hand, and, on the other hand, as ignorant and infant-like pagans. In relation to North American Indians, the short visit of Buffalo Bill's Wild West Show to Barcelona in 1889-1890, the filming of the famous spaghetti westerns in south-eastern Spain (1960s and early 1970s), and the high volume of publication of dime novels, most of them pseudotranslations (see Camus Camus, 2010), during Franco's Dictatorship (1939-1975), constitute the most important experiences that Spanish audiences could get in recent times. This contrasts greatly with, for instance, the Italian reception of literature concerning the indigenous populations of the Americas: thanks to the opening of an American bookstore in Milan in the mid-1800s, Italy was ready to jump from the academic to the popular market in the 1950s (Giordano, 1987, p. 491) and, finally, to the Italian translations of contemporary North American Indian authors at the end of the 1970s, "sooner than in other European languages”(Giordano, 1994, p. 102).

Such differences corroborate the fact that the incorporation or omission of certain images of the Other is too frequently connected with a more or less explicit agenda in relation to the centrality of the Self. After all, the accepted images of the Other 
"are either the expression of a literary tourist mentality addicted to a nouveaumania whose easily jaded sensibilities cry out for new supplies of exotica or they are underhanded efforts to defend the Western imperialist, pro-bourgeois status quo in the cultural domain" (Chinweizu and Madubuike, 2005, p. 191). Therefore, the study of the Spanish images of Indianness requires a combined diachronic and synchronic approach that attends not only to the historical compilation of cultural and identitarian meaning, but also to the isolated appreciations of the Other in a given moment.

Keeping in mind that translation processes are essential "for the spread and the international success of a book and for the image of a foreign people described in that book" (Soenen, 1995, pp. 1718), it is necessary to study in depth those parts of the renderings into Spanish which can offer information about the undefined Spanish version of Indianness. Even if the linguistic choices of translators may show the "values, beliefs, and representations that enjoy great esteem in the receiving culture"(Venuti, 2008, p. 39), the most appealing elements in relation to imagological representations of Indians are the paratexts and more specifically the peritexts, as observed above. This "certain number of verbal or other productions [that] surround [the text] and extend it, precisely in order to present it" (Genette, 1997, p.1) provides much interesting information because of "their special role as mediators between the text and the reader and their potential influence on the reader's reading and reception of the works in question" (Kovala, 1996, p. 120).

The mediating role of peritexts is even more relevant to the present study, which deals with texts containing a minority discourse. Peritexts, then, "necessarily contain a higher quotient of 'foreignness"'(Watts, 2000, p. 42), one that has to be decoded for the readers according to their assumptions, expectations and interest in that foreignness. As the doorsteps of books and the central elements of their promotion, they inform the readers not only of the contents, but of the ideology behind the selection, repackaging and consumption of those texts and the Other identities within them. The (trans)cultural connotations of these representations only become explicit in the peritext where editors/publishers and other literary actors and translation agents state in multiple ways what an Indian is through Spanish eyes.

Following the specifications of Genette (1997, p. 16), the peritextual elements that are observed in the present paper range 
from general formal aspects (format, series, publishing houses) to the actual book covers and dust jackets, which include the titles and physical images or photographs, as well as the biographical and bibliographical information about the author and the work. ${ }^{5}$ Last but not least, the prefaces will occasionally be used for they contribute interesting insights into Spanish ideas of the identity of Native Americans. ${ }^{6}$ The footnotes by the translators, although considered peritexts in relation to translations, are not included in this study, for they provide us with little information about the imagological representation of Indians by Spanish agents of translation.

\section{Analysis of the Spanish Peritexts}

As was stated above, the Spanish renditions of Native American literature do not share a common profile of publications, so the results of the analysis are presented here in thematic and functional groups.

\subsection{Olañeta's Model for Anthropological Books}

There is one publisher that stands out because it has published almost one third of all translations of Native American literature available in Spain. This publisher, José J. de Olañeta, has developed a very specific editorial format that aims at portraying the different texts as archival documents of great research interest. The physical characteristics (an ochre color range for the background, the use of black and dark brown for textual features, and the inclusion of either drawings in faded colors or black and white photographs) emphasize the idea of offering readers old and delicate scrolls, whereas the verbalized elements in the peritexts point out the value of the information provided by those books.

In relation to the Indian identities, Olañeta's format is especially relevant because it emphasizes the apparent importance of the selected texts for understanding the indigenous cultures of the United States. Since the peritexts of these anthropological books do not include a biographical section, any information about the authors is intermingled in the summary of the book's contents,

5. The present analysis is confined to the Spanish peritexts, although a contrasting study of the original peritexts would prove very interesting.

6. It is necessary to point out that prefaces appear only in four of the 47 translations available in Spanish, making them a complementary material, rather than a central one. 
resulting in stereotypical ${ }^{7}$ comments about the mythical simple life of the Indians. In La vida en los bosques: recuerdos de la infancia de un indio sioux [Life in the woods: Memories from the childhood of a Sioux Indian] (Eastman, 1999, front flap), it is said that Charles A. Eastman led a traditional life, "de cazadores nómadas y guerreros" ["of nomadic hunters and warriors"], a way of living "desaparecido hace ya mucho tiempo" ["vanished too long ago"]. Because these books focus on anthropology and (auto)biographies, the claim is that they present "una visión general completa y auténtica del modo de vida de los [indios] antes de la invasión blanca" ["a general complete and authentic vision of the [Indian] lifestyle before the White invasion"] (Standing Bear, 1995, back cover), one that cannot be found nowadays because of its near extinction (Hungry Wolf, 1998, front flap).

The visual representation of Indians through the front and back cover photographs and drawings also asserts identities clinging to romanticized visions of a historical past that will never return. The photographs collectively show more or less famous individuals wearing feather headdresses and tribal costumes, posing in the repetitive postures of the nineteenth century anthropological collections of Edward S. Curtis and Frank A. Rinehart (see Eastman, 1995 and 1999; Hungry Wolf, 1998; Hungry Wolf and Hungry Wolf, 1991; Neihardt, 1998 [1971], reprinted by this publishing house). The drawings follow the same pattern and show Native Americans portrayed in regalia (see Standing Bear, 1995; Eastman, 1994), but in two cases-Eastman's El explorador indio: saberes y artes prácticas del indio americano [The Indian Explorer: Knowledge and Practical Arts of the American Indian] and Mourning Dove's Cuentos indios del coyote [Indian Coyote Stories]—the cover artwork stresses other stereotypical aspects such as the spiritual connection of Indians with animals and the environment, emphasizing "las lecciones que aprendió de la naturaleza" ["the lessons that he learnt from nature"] (Eastman, 1989, front flap).

The resulting image of Native Americans is particularly meaningful because all of Olañeta's peritextual elements grouped

7. I use the term "stereotype" in the sense of "a generalization about a group of people in which incidental characteristics are assigned to virtually all members of the group, regardless of actual variation among the members [and] of new information" (Aronson et al., 2005, p. 434, quoted in Beller, 2007, p. 429). 
together project to readers the impression that these books are scientific rather than artistic documents worthy of attention. After all, according to Olañeta's representation of Indianness, these communities are condemned to an ever-lasting past surrounded by romantic circumstances and only accessible through anthropological products. The few Indians, if any, still around are the last links in a traditional chain of wisdom and spiritual bearers (Hungry Wolf, 1998, front flap), so the compilation of their knowledge turns out to be urgent and mandatory.

This discourse focusing on the Indians as the vanishing America does not originate with the Spanish agents of translation. In fact, it goes back to the US and at least the 1700s, and was reinforced in the following centuries by means of government policies, anthropological and photographical compendia, and popular entertainment. As King points out, society has been "left with a series of historical artifacts and, more importantly, a series of entertainments" (2012, p. 20). Neither is the "vanishing America" discourse unique in overcoming the boundaries of time and cultures: "Dead Indians" are everywhere, for they are "the stereotypes and clichés that North America has conjured up out of experience and out of its collective imaginings and fears" (ibid., p. 53). The vanishing America has, thus, often been accompanied and emphasized by the images of the noble savage, the heroic warrior or the shamanistic sage, presenting the disappearance of the Indian cultures as a romanticized cultural loss. Then, each publication, each translation becomes an attractive revision of these lost cultures, " $[\mathrm{u}] \mathrm{n}$ documento auténtico [...] y un relato apasionante que se apodera del interés del lector hasta la última página” ["an authentic document [...] and a thrilling account that takes control of the reader's interest to the last page"] (Neihardt, 1998 [1971], back cover).

\subsection{Contextualizing the Native American World}

This model of peritextual formatting and contents has been partially reiterated by other publishing houses, namely Erasmus Ediciones, Miraguano, Montesinos Editor, and Muchnik Editores. All four publishers fail to fully avoid stereotypical visions of Native American cultures, although they do not follow the colonialist approach of Olañeta; neither is the selection restricted to anthropology. The end result, as observed below, is an Indianness consistent with the mythical image of the indigenous spirituality 
and culture under imminent threat, but, at the same time, present and active in the contemporary world.

This is the case of the peritext of Ray A. Young Bear's Restos de la primera tierra [Remnants of the First Earth] (1988), published by Muchnik Editores. On the cover, there is a picture of a bald eagle flying among skyscrapers, a reference to Indian spirituality as well as an indication of the urban condition of contemporary Native Americans. The biographical information about Young Bear brings up his artistic development and how his works have been praised by The New York Times as "una suntuosa muestra de literatura" ["a sumptuous sample of literature"] (Young Bear, 1988, front flap). However, the summary shows a more stereotypical point of view about Indian communities, claiming that the book is " $[\mathrm{u}] \mathrm{n}$ canto desesperado, pero a la vez orgulloso, a la redención de un pasado perdido" ["a desperate song, but at the same time proud, for the redemption of a lost past"] (ibid., back cover).

Less insightful is the cover artwork of the most recent translation of Zitkala-Ša's productions, Recuerdos de una india sioux [Memories of a Sioux Indian] (2011), for it is a black and white drawing of a archetypical Native girl: feathered hair band and long braids, big earrings and a beaded necklace as jewelry. The summary, on the other hand, gives relevant information about the author's experiences contained in the book, such as how she had to "abrirse paso en un mundo de hombres blancos imbuido de solapado o abierto racismo" ["make her way in a white men's world filled with veiled or plain racism"] (ibid., back cover). Even if some of the expressions used by Erasmus Ediciones are charged with stereotypes- "genuina nativa del pueblo dakota" ["genuine Native of the Dakota people"], "ese universo enigmático" ["that enigmatic universe"], "la rica y secreta lengua de su pueblo" ["the rich and secret language of her people"] (ibid.) - this peritext includes a small reflection on the cultural circumstances surrounding the original text and the author, breaking up some myths about the Indians and their alleged disappearance.

The verbal peritext constructed by Montesinos Editor for Ortiz's anthology El poder de la tierra: cuentos indios norteamericanos [Earth Power: North American Indian Tales] (1988) represents a third case. Despite the characteristic image of an Indian elder on the cover, the summary expresses how the short stories within, in their "amplia variedad de estilos, temas y cuestiones" ["wide variety of 
styles, topics and issues"] (ibid., front flap), are a way to make "[que] el pueblo permanezca plenamente consciente y responsable de sus relaciones sociales, económicas, políticas, culturales y espirituales" ["the people remain fully aware and responsible of their social, economic, political, cultural and spiritual relations"] (ibid.). The incorporation of such a description of Native American literatures helps to conceptualize the indigenous identities more realistically, as belonging to the present: powerful and heterogeneous and working for their endurance.

Last but not least, the peritextual contextualization for Tehanetorens's Cuentos de los Indios Iroqueses [Tales of the Iroquois Indians] (1984) and Zitakala-Ša's Cuentos y Leyendas de los Indios Sioux [Tales and Legends of the Sioux Indians] (1994) works more efficiently, making the books "más amenos y comprensibles" ["more enjoyable and understandable"] ("Miraguano Ediciones Colecciones", n.p.). The publishing house incorporates a booklet into its publications, with information about the life and times of the authors "que aporta una idea más clara que la mera traducción de los cuentos al castellano" ["that gives a clearer idea than the one given by the simple translation of the tales into Spanish"] (Tehanetorens, 1984, front flap). These booklets, both written by the same editor, José Javier Fuente del Pilar, are inaccurate from a scholarly perspective; nevertheless, at least they do not prejudice the audience against the Indian identity in the text, quite the contrary: the intermingling of Eurocentric categories and Native concepts actually benefits the transcultural comprehension of both inexperienced and well-informed readers of Indianness and its complexities.

\subsection{Fictional Novels}

When fictional novels are taken into account, the configuration of Indianness in the peritextual elements is approached in a drastically different way. This is not a surprising situation, though. The marketing of fictional books as opposed to those focused on anthropology and (auto)biographies emphasizes other distinctive aspects, such as the captivating beauty, the refreshing humor and the rhetorical power of these narratives. Also, publishing houses that offer fictional novels include the author's biographical information as a separate section: after all, unlike in the anthropological publications, the contents of the fictional books are not dependent on the life experiences of the writer, and there is no reason to state 
how authentic the vision of the author actually is about the topics in the text.

In addition, the verbal peritexts of the fictional novels tend to underline the thematic particularities of the individual works: love, adventure and transcultural disagreement are usually pointed out as essential narrative elements, whereas the similarities between these productions and other minor literatures as well as some cultural referents are mentioned only occasionally. Besides this, the visual elements of the book covers and dust jackets do not follow any particular pattern, either in relation to each other or in relation to the model constructed by Olañeta. This is due to the fact that a total of 17 different publishing houses participate in the publication of translations of fictional novels, making it very difficult, almost impossible, to construct by knowledge-accumulation a certain sense of Native American literatures.

Such variety of representations and points of view among the various participants in the recontextualization of North American Indian identity has two divergent outcomes: one that leaves Indianness aside as an exotic, secondary component of the narrative, and one that reinforces the presence of the Other as an essential part of the fiction inside the covers. Authors associated with the first branch of peritextual representation are Louise Erdrich, Susan Power and Velma Wallis, even if their novels deal with Native American land, identity, cultural and political concerns, as much as the writings by Sherman Alexie, Michael Dorris and N. Scott Momaday, all connected with an explicit Indianness.

The hidden Indianness of some translations is managed by the strategic locations and configurations of the different peritextual elements. The translations of Erdrich's, Power's, and Wallis's books show these features in various combinations that, although they have diverse specific outcomes, contribute to a generalized perception of the Other as an element of commercial unimportance beyond the commodified use of its exotic characteristics. In this way, Indianness becomes an acceptable intermittence in the promotion of these translations, precisely because of its limited manifestation in the peritexts: a more explicit and more accurate representation of Native American reality might have a more negative commercial impact on the audience.

First of all, the concealment of the Indian presence is achieved by eliminating the cultural references in the translated titles. Susan 
Power's The Grass Dancer, for instance, indicates a style of powwow dancing, a central topic of her story; in the translation, this reference has been eliminated and substituted by a culturally empty headline, Visteme de hierba [Dress Me in Grass] (1996). The two translations of Wallis's works into Spanish also show titles in which the mention of Indianness in the original ones has been erased: Two Old Women: An Alaskan Legend of Betrayal, Courage and Survival became Las dos ancianas [The Two Old Women] (1997a), and Bird Girl and the Man Who Followed the Sun: An Athabaskan Indian Legend from Alaska was translated as Tras el sol [After the Sun] (1997b).

Secondly, the information about the contents of the translations tends to avoid extensive details about the Native American cultures, emphasizing, rather, stereotypical attributes that place Indians among many other components of the story, many of them the usual elements of these fictions. Wallis's summaries connect "las frías tierras de Alaska" ["the cold lands of Alaska"] (1997b, back cover) with the learning experience of her characters, who become "más sabios y capaces de resistir las penalidades de la vida" ["wiser and more able to endure life's hardships"] (ibid.), mastering "el valor de la tradición" ["the value of tradition"] (ibid.) and "la calidez de un mensaje espiritual que busca y encuentra amor en los gestos más humildes y en las voces más sinceras" ["the warmth of a spiritual message that looks for and finds love in the most humble gestures and in the most sincere voices"] (1997a, back cover). The most recent publications of Erdrich's translations camouflage the Indian presence so well that, in each summary, only a few words can be found referring to it: life on the reservation and tribal affiliations get most of the focus $(2003,2010$ c, 2013, and 2014), although allembracing allusions such as "un pintor amerindio" ["an Amerindian painter"] (2010a, back cover) or "la comunidad india" ["the Indian community"] (2014, back cover) are sometimes used to indicate the ethnic affiliation of the characters.

The summary of Power's Visteme de hierba is even more misleading than those of Wallis and Erdrich: it is intentionally placed on the flaps of the dust jacket, hiding one of the very few cultural references to Indianness in the peritext, i.e., a brief explanation of the differences between two powwow dancing styles (Power, 1996, front flap). This unusual location leaves the back cover of the book free for the inclusion of several excerpts of reviews from important American journals and famous writers, 
a successful technique of promotion. These comments range from the typical praises of Power's writing style- "prosa de suprema belleza" ["prose of supreme beauty"] (Elle cited in Power, ibid., back cover) - to subjective connections with a "magia poderosa en estado puro" ["powerful magic in its pure state"] (Amy Tan cited in ibid.) and with "el poderoso legado del amor y de los celos" ["the powerful legacy of love and jealousy"] (Los Angeles Times cited in ibid.). The summary, for its part, reinforces this stereotypical contextualization of fiction, stating that the book observes "las relaciones entre los hombres y la naturaleza" ["the relationship between men and nature"] in a "laberinto de un siglo y medio de amor y de traición" ["century-and-a-half labyrinth of love and treason"] and "una trama de pasiones atemporales" ["a fabric of timeless passions"] (ibid., front flap).

Erdrich's summaries also provide this idealized projection of the context for commercial purposes by means of a complex combination of magic and love-related elements. In all her translations, the summaries point out the importance of love, passion and destiny to the stories, sometimes in enthusiastic ways"un canto a la sensualidad y [...] la auténtica receta para elaborar un poderoso filtro de amor" ["a song to sensuality and [...] the authentic recipe to prepare a powerful love potion"] (Erdrich,2010b, back cover); "una reflexión sobre el dinero, el amor desesperado y la esperanza inquebrantable, sobre el poder inagotable de los sueños más preciados" ["a reflection about money, desperate love and unbreakable hope, about the tireless power of the most precious dreams"] (Erdrich, 2014, back cover) -and sometimes in a calmer mode: "su apego a Gil está jalonado de sombrías necesidades" ["her attachment to Gil is punctuated by dark necessities"] (Erdrich, 2010a, back cover).

There are some exceptions to this type of summary, specifically in relation to the first half of translations of Erdrich's works published in Spain. The details given in the summaries about the books' contents seem to present the North American Indian reality with comments about how the indigenous population has been "desposeída por el hombre blanco de cultura, religión y poder económico" ["dispossessed by the white man of their culture, religion and economic power"] (Erdrich, 1987, front flap). Following Erdrich's activist attitude towards the political and sociocultural concerns of Native American tribes, her stories deal with 
"los conflictos que desgarran a una pequeña comunidad india de Dakota del Norte cuando ciertas tribus luchan todavía por retener lo poco que les queda de sus tierras" ["the conflicts that tear up a small Indian community in North Dakota when certain tribes are still fighting to retain the little land they keep"] (Erdrich, 1990, back cover), but the rest of the peritext shows a highly stereotypical image of Indianness.

In fact, the images used in the translations of her works, as well as in the first edition of Wallis' Las dos ancianas (1997a), portray Native Americans in culturally disrespectful terms. The illustrations cover almost every possible misrepresentation from noble savages to primitivism, including temporal discrepancies with the stories. The peaceful Indian playing a flute by a stream (Erdrich, 1987) and the heroic warrior wandering alone in Frederic Remington's 1909 The Outlier (Erdrich, 1990) turn the apparent engagement with Indian politics of the corresponding summaries upside down. In a similar way, a photograph of tipis in a wintry landscape is not the most effective illustration for a book dealing with an Ojibwe reservation and the contemporary situation of Indians (Erdrich, 2003). As for the pictures selected for Wallis's Las dos ancianas (1997a)-some primitive-like schematic drawings of human figures made of simple lines and imprecise blots - they only contribute to hide the connection of the book with Native American cultures even more or to associate this Alaskan legend with primitive societies unable to master artistic complexity.

On other occasions, the artwork has no connection with the US indigenous tribes. The cover of Power's translation (1996) shows a bare foot in a field of red flowers, the audience being unaware that any Native American association with the traditional moccasins in the US edition of the book has been eliminated. Most editions in Spanish of Wallis's books (1997a and 1997b) also delete Indianness from their covers: one edition, for instance, has a random landscape with a solitary tree, and the other offers a picture of mountains half covered in snow, with an overprint reading "New Age".

The biographies are a completely different matter, with the exception of Wallis whose biographical note simply states that she comes from "una pequeña comunidad del noroeste de Alaska" ["a small community in Northwest Alaska”] (Wallis, 1997a, front flap) without further explanations about that community. The information about Susan Power and about Louise Erdrich, 
however, puts the emphasis on the authors' tribal and family links to the ethnic reality of Native Americans. It is pointed out that Power is "miembro de derecho de la tribu sioux de la reserva de Standing Rock" [a "full member of the Sioux tribe of the Standing Rock reservation"] (Power, 1996, back flap), although it is not explained what "full member" means or what the conditions are to become one. Her biographical information also highlights her direct family relationship with an Indian chief, a signer of the Declaration of Independence and a governor of the State of New Hampshire (ibid.). Of Erdrich, it is pointed out that she "desciende de la tribu india ojibwe y de emigrantes franceses y alemanes" ["descends from the Ojibwe tribe and from French and German emigrants"] (2010b, front flap) and that "[s]u abuelo era el jefe de la tribu de la reserva" ["her grandfather was the chief of the tribe in the reservation"] (1987, back flap).

These stereotypical representations of North American Indian identity contrast sharply with the image offered by the publishing houses which have edited the Spanish translations of works by Sherman Alexie, Michael Dorris and N. Scott Momaday. Although these publications vary in their thematic scope and in their degree of explicitness (for instance, Dorris's book is aimed at children, so his narrative is less politically engaged than Alexie's or Momaday's), they all portray Indians and Indianness as a modern, realistic entity characterized by broad variability. The peritexts make use of the Native American presence not only to sell copies, but also to open the eyes of the Spanish audience to new transcultural visions unaffected by (neo)colonial depictions of the Other. The summaries, the biographical notes and the illustrations, which will be analyzed below, show Indians in a new light, with common lives and everyday stories.

The contents of this group of translations are presented to their potential readers in unsophisticated ways, without romantic exaggerations or bombastic expressions. The simplicity of the summaries matches the mundaneness of the narratives, which are stories "de la reserva, de indios y blancos, de alcohol, de amor y muerte" ["about the reservation, about Indians and Whites, about alcohol, about love and death"] (Alexie, 1994, back cover). These books tell how Native Americans founder between two cultures in the modern multicultural society (Momaday, 2011, back flap) or how they are able to "integrarse plenamente en la tribu" ["fit fully 
in the tribe"] in the era of the discovery of America (Dorris, 1995, back cover). The indigenous characters are portrayed as "taínos que viven en una isla del Caribe" ["Taínos living in a Caribbean island"] (ibid.), a "indio veterano de la segunda guerra mundial y expresidiario" [an "Indian veteran of the World War II and former convict"] (Momaday, 2011, back flap), "la clase media y alta, los burócratas, los profesionales y los poetas" ["the middle and the high class, the bureaucrats, the professionals and the poets"]; to put it briefly, those Native Americans who "apenas aparecen en la literatura" ["barely appear in literature"] (Alexie, 2001, back cover).

This kind of representation, fortunately, certifies that Indians did not vanish after the Europeans arrived on the American continent: in fact, they are part of the present, share similar dilemmas with Euro-Americans and do not restrict their experiences to those unrealistically descriptions attributed to the Other in the modern world. Stereotypical identities, such as the ones presented in the peritexts of Erdrich, Power and Wallis, have made it necessary to point out that Native Americans "también viajan en avión, trabajan en oficinas y conocen la cultura pop" ["also travel by plane, work in offices and know pop culture"] (Alexie, 2010, back cover). Nonsensical as they may seem, these remarks are effective in deconstructing the myths surrounding Native Americans and promoting the understanding that Indians also experience our postmodern world.

The characters' ordinary identities are not the only ones depicted in plain, unembellished form: the authors' biographical notes also emphasize the normality of these writers, even if their ethnicity is very different from that of the target readers. In the first translation into Spanish of Alexie's works, he is presented as a Spokane/Coeur d'Alene who graduated from the University of Washington and Washington State University, and whose prolific production of poetry, short stories, essays, reviews, and translations have granted him wide recognition (1994, front flap). In one of the most recent translations, only a few details of Alexie's life are given: his work as a novelist, poet and filmmaker, his tribal affiliation, the titles of other translated books, and a short mention of the critics' praise for him (2009, back cover). Unlike Erdrich's and Power's biographies, Alexie's do not elaborate on the indigenous links of the author, but on his literary achievements and his active life in the arts. 
Something similar happens with the information about Dorris and Momaday. Very briefly, the peritexts indicate the Indian tribes of which these authors are members, as well as their academic preparation: Dorris, "[d]escendiente de indios modoc, estudió en Georgetown y se doctoró en Antropología en Yale" ["descendant of Modoc Indians, studied in Georgetown and earned his PhD in Anthropology at Yale"] (Dorris, 1995, back cover); Momaday, "kiowa por parte de padre y cherokee por parte de madre" ["Kiowa on his father's side and Cherokee on his mother's"], "[1]icenciado por la Universidad de Nuevo México" ["graduated from the University of New Mexico"], and has a $\mathrm{PhD}$ in English Literature from Stanford University (Momaday, 2011, front flap). Their artistic productions are also highlighted. Dorris's biography points out his versatility as a writer of adult and children's novels and how some of his books "se han llevado al cine y a la televisión" ["have been brought to cinema and to television"] (Dorris, 1995, back cover). The information about Momaday is broader than that about Dorris because Momaday is considered "el iniciador del Renacimiento native americano" ["the initiator of the Native American Renaissance"] (Momaday, 2011, front flap): his books, essays, reviews, newspaper articles, discourses, and thesis have earned him "numerosos galardones nacionales e internacionales, [...] el nombramiento de Artista para la $\mathrm{Paz}$ otorgado por la UNESCO (2004) [y] la Medalla Nacional de las Artes" ["many national and international prizes, the appointment as the UNESCO Artist for Peace (2004) and the National Medal of Arts"] (ibid.)

Such contextualization of the lives of these writers has important consequences in relation to the Spanish conceptualization of the Indian identity. First of all, these biographies make no claims about the authenticity of the writers' ethnicity: in these peritexts there is, for instance, no reference to famous ancestors or to a life in the romanticized historical past assigned to Native American cultures. Secondly, the information about the authors focuses attention on their literary merits, portraying them as autonomous storytellers whose artistic value does not depend on their indigenous condition, but on their talent.

The illustrations accompanying these kinds of summaries and biographical notes are equally respectful of the cultural and artistic diversity of North American Indians. The publisher of Dorris's 
translation has added a series of internal drawings and a cover image made by a famous Spanish illustrator for children's books, "teniendo en cuenta la documentación y los objetos existentes en el Museo de la Fundación García Arévalo de la República Dominicana" ["taking into account the documentation and objects existing in the Museo de la Fundación García Arévalo in the Dominican Republic"] (Dorris, 1995, p. 8). For Alexie's and Momaday's books, illustrations showing the artistic variety of the indigenous communities have been selected for the Spanish editions: Alexie (1994) is given for a cover a drawing by the Kiowa ledger artist Silver Horn, and Momaday (2011) a painting by Navajo artist David K. John. The fact that the pictures may not match the tribes included in the narrations does not shadow the interplay between written and visual art; it actually emphasizes the identity dialogue between the literary production of these writers and their communities of origin.

The combination of all these elements highlights the presence of the Indian Other as an attractive identity on its own, not just in relation to the conquest of America by White society. The incorporation of explicit images and commentaries about the Indigenous reality, both traditional and modern, in the peritexts of the Alexie, Dorris and Momaday translations offers a new perspective on the marketing of Native American literature in Spain. In fact, these peritexts put into question the promotion strategies applied to the books of Eastman, Erdrich, Standing Bear or Wallis, among others, for they show the economic operability of addressing the North American Indian presence without undervaluing its cultural dimension.

\section{Conclusion}

The above analysis of the peritextual elements surrounding the Spanish translations has proved that most publishing houses share a stereotypical vision of Indianness. Even those peritexts that represent Native Americans as modern active members of culture and society implicitly participate in the underlying, traditional description of Indians in romanticized terms: they use it, at least, as a point of departure for their deconstructive discourse. Thus, all the images of the Other in the peritexts for such translations, either by means of repetition or by means of opposition, confirm the prototypes of Native Americans that the Spaniards created and shared over the years. 
The common beliefs about North American Indian identity shared by the publishing houses mean that, with a high frequency, stereotypical Indianness is used in the rewrapping of the translations in order to promote these texts. The most important consequence is the perpetuation of a culturally disrespectful discourse about Native Americans in relation to ethnicity, history and art. More specifically, the editorial accumulation of these romanticized images implies the commodification of the Native American reality in (neo)colonial economic terms.

Fortunately, alternatives are already being employed to market the literature authored by Native Americans in Spain. As was observed in the descriptive analysis, certain publishing houses aim at showing the present reality of the indigenous communities. The peritexts that introduce the Spanish audience to a new vision of the Other demonstrate successfully that stereotypes are not the only possible representations of North American Indians, and that renovated images of Indianness can be spread. In addition, these publications establish that the advertisement of Native American literature translated into Spanish does not have to be linked with a limited range of representations: instead, these renditions can be promoted in multiple ways without looking down on the historical and contemporary diversity of the Indian identity and its cultural and literary expression.

\section{References}

Alexie, Sherman (1994). La pelea celestial del Llanero Solitario y Toro [The Heaven Fistfight of Lone Ranger and Tonto]. Trans. Marco A. Galmarini. Barcelona, El Aleph.

Alexie, Sherman (2001). El indio más duro del mundo [The Toughest Indian in the World]. Trans. Antonio Padilla. Barcelona, El Aleph.

Alexie, Sherman (2009). El diario completamente verídico de un indio a tiempo parcial [The Completely True Diary of a Part-Time Indian]. Trans. Clara Ministral. Madrid, Siruela.

Alexie, Sherman (2010). Diez pequeños indios [Ten Little Indians]. Trans. Daniel Gascón. Zaragoza, Xórdica.

Bataille, Gretchen M. (2001). "Introduction.” In G. M. Bataille, ed. Native American Representations: First Encounters, Distorted Images, and Literary Appropriations. Lincoln, University of Nebraska Press.

Beller, Manfred (2007). “Stereotype.” In M. Beller and J. Leerssen, eds. Imagology: The Cultural Construction and Literary Representations of National Characters. Amsterdam and New York, Rodopi. 
Bevis, William (1995). "Wylie Tales: An Interview with James Welch." Weber: The Contemporary West, 12, 3. [http://weberstudies. weber.edu/archive/archive\%20B\%20Vol.\%2011-16.1/Vol.\%20 12.3/12.3WelchBevis.htm].

Camus Camus, Ma Carmen (2010). "Censorship in the Translations and Pseudo-Translations of the West." In D. Gile et al., eds. Why Translation Studies Matters. Amsterdam/Philadelphia, John Benjamins.

Carbonara, Lorena (2009). Writing from the Contact Zone: Native American Autobiography in the Nineteenth Century. Rome, Aracne Editrice.

Chinweizu, Onwuchekwa Jemie and Ihechukwu Madubuike (2005). "The African Novel and its Critics (1950-1975)." In G. Desai and S. Nair, eds. Postcolonialisms: An Anthology of Cultural Theory and Criticism. New Brunswick, Rutgers University Press.

Deloria, Vine (1975). El general Custer murió por vuestros pecados: un manifiesto indio [Custer Died For Your Sins: An Indian Manifesto]. Trans. H. Valentí. Barcelona, Barral.

Dorris, Michael (1995). Tainos [Tainos]. Trans. Miguel A. Martínez. Madrid, Ediciones Alfaguara.

Eastman, Charles A. (1989). El Explorador indio: saberes y artes prácticas del indio americano [The Indian explorer: Knowledge and Practical Arts of the American Indian]. Trans. Jordi Quingles. Palma de Mallorca, José J. de Olañeta.

Eastman, Charles A. (1994). Indios de antaño [Ancient Times' Indians]. Trans. Eduardo Jordá. Palma de Mallorca, José J. de Olañeta.

Eastman, Charles A. (1995). El alma del indio [The Soul of the Indian]. Trans. Esteve Serra. Palma de Mallorca, José J. de Olañeta.

Eastman, Charles A. (1999). La vida en los bosques: recuerdos de la infancia de un indio sioux [Life in the Woods: Childhood Memories of a Sioux Indian]. Trans. Esteve Serra. Palma de Mallorca, José J. de Olañeta.

Erdrich, Louise (1987). Filtro de amor [Love Filter]. Trans. Carlos Peralta. Barcelona, Tusquets Editores.

Erdrich, Louise (1990). Huellas [Tracks]. Trans. Carlos Peralta. Barcelona, Tusquets Editores.

Erdrich, Louise (2003). El último informe del padre Damián [The Last Report by Father Damian]. Trans. Albert Borràs. Barcelona, Ediciones del Bronce.

Erdrich, Louise (2010a). El juego de la sombra [Shadow Game]. Trans. Susana de la Higuera. Madrid, Siruela.

Erdrich, Louise (2010b). Filtro de amor [Love Filter]. Trans. Carlos Peralta and Susana de la Higuera. Madrid, Siruela. 
Erdrich, Louise (2010c). Plaga de palomas [Plague of Doves]. Trans. Susana de la Higuera. Madrid, Siruela.

Erdrich, Louise (2013). La casa redonda [The Round House]. Trans. Susana de la Higuera. Madrid, Siruela.

Erdrich, Louise (2014). Bingo Palace [The Bingo Palace]. Trans. Susana de la Higuera. Madrid, Siruela.

Genette, Gérard (1997). Paratexts: Thresholds of Interpretation. Trans. Jane E. Lewin. Cambridge, Cambridge University Press.

Giordano, Fedora (1987). "North American Indians in Italian (19501981): A Bibliography of Books." In C. F. Feest, ed. Indians and Europe: An Interdisciplinary Collection of Essays. Aachen, Ed. Herodot.

Giordano, Fedora (1994). “The Anxiety of Discovery: The Italian Interest in Native American Studies." RSA Journal, 5, pp. 81-109.

Hall, Stuart (1996). "Introduction: Who Needs Identity?" In S. Hall and P. du Gay, eds. Questions of Cultural Identity. London, Thousand Oaks; New Delhi and Singapore, SAGE Publications.

Herrero López, Isis (2013). La traducción al español de la prosa nativoamericana: estudio crítico de la (re)construcción transcultural de la identidad indigena estadounidense. Ph.D. dissertation. Universidad de Salamanca. Unpublished.

Horáčková, Eva (2010).Erdrich, Momaday and Silko in the Context of Czech Translation. MA dissertation. Masaryk University. Unpublished.

Hungry Wolf, Beverly (1998). La vida de la mujer piel roja: cómo vivian mis abuelas [The Life of the Redskin Woman: How My Grandmothers Lived]. Trans. Esteve Serra. Palma de Mallorca, José J. de Olañeta.

Hungry Wolf, Beverly and Adolf Hungry Wolf (1991). Los hijos del sol: relatos de los niños pieles rojas [Children of the Sun: Tales of the Redskin Children]. Trans. Esteve Serra. Palma de Mallorca, José J. de Olañeta.

Kalshoven, Petra Tijske (2012). Crafting the Indian: Knowledge, Desire and Play in Indianist Reenactment. Oxford, Berghahn Books.

King, Thomas (2012). The Inconvenient Indian: A Curious Account of Native People in North America. Toronto, Doubleday Canada.

Kovala, Urpo (1996). "Translations, Paratextual Mediation, and Ideological Closure." Target, 8, 1, pp. 119-147.

Krupat, Arnold (2000 [1996]). "Postcolonialism, Ideology, and Native American Literature." In A. Singh and P. Schmidt, eds. Postcolonial Theory and the United States: Race, Ethnicity, and Literature. Jackson, University Press of Mississippi.

Krupat, Arnold (2002). Red Matters: Native American Studies. Philadelphia, University of Pennsylvania Press.

Kuran-Bürçoğlu, Nedret (2000). "At the Crossroads of Translation 
Studies and Imagology." In A. Chesterman et al., eds. Translation in Context: Selected Contributions from the EST Congress, Granada, 1998. Amsterdam/Philadephia, John Benjamins.

Leerssen, Joep (1991). "Echoes and Images: Reflections Upon Foreign Space." In R. Corbey and J. Leerssen, eds. Alterity, Identity, Image. Selves and Others in Society and Scholarship. Amsterdam and Atlanta, Rodopi.

Leerssen, Joep (2007). "Imagology: History and Method.” In M. Beller and J. Leerssen, eds. Imagology: The Cultural Construction and Literary Representation of National Characters. A Critical Survey. Amsterdam and New York, Rodopi.

Momaday, N. Scott (2011). La casa hecha de alba [House Made of Dawn]. Trans. Amelia Salinero. Alicante, Appaloosa.

Mourning Dove (1994). Cuentos indios del coyote [Indian Coyote Stories]. Trans. Carmen Bravo-Villasante. Palma de Mallorca, José J. de Olañeta.

Neihardt, John G. (1932). Black Elk Speaks. New York, William Morrow \& Company.

Neihardt, John G. (1998 [1971]). Alce Negro habla [Black Elk Speaks]. Trans. Juan A. Larraya. Palma de Mallorca, José J. de Olañeta.

Ortiz, Simon (1988). El poder de la tierra: cuentos indios norteamericanos [Earth Power: North American Indian Tales]. Trans. Agustín Gil. Barcelona, Montesinos Editor.

Power, Susan (1996). Visteme de hierba [Dress Me in Grass]. Trans. Flavia Company. Barcelona, El Aleph.

Proyecto Filosofía En Español (2012). “Tusquets Editores.” [www. filosofia.org/bol/bib/tusquets.htm].

Rättyä, Kaisu (2001). "Kirjan Kansikuva Periteksinä [The cover image of a book as a peritext].” In K. Rättyä and R. Raussi, eds. Tutkiva Katse Kuvakirjaan [Investigative Gaze into the Picture Book]. Helsinki, NTJ Kirjastopalvelu Oy.

Robyns, Clem (1994). “Translation and Discursive Identity." Poetics Today, 15, 3, pp. 405-428.

Soenen, Johan (1995). "Imagology in the Framework of Translation Studies.” In J. Soenen, ed. Bella: Bijdragen over Vertalen, Imagologie en Literatuur-Essays on Translation, Imagology and Literature. Antwerp, Linguistica Antverpiensia.

Standing Bear, Luther (1995). La tierra del águila moteada [The Land of the Spotted Eagle]. Trans. Eduardo Jordá. Palma de Mallorca, José J. de Olañeta.

Summers, Caroline (2013). “What Remains: The Institutional Reframing 
of Authorship in Translated Peritexts." In V. Pellat, ed. Text, Extratext, Metatext and Paratext in Translation. Newcastle upon Tyne, Cambridge Scholars Publishing.

Swann, Brian, ed. (2011). Born in the Blood: On Native American Translation. Lincoln, University of Nebraska Press.

Taylor, Colin F. (1988). "The Indian Hobbyist Movement in Europe." In W. E. Washnburn, ed. Handbook of North American Indians. Vol. 4: History of Indian-White Relations. Washington, DC, Smithsonian Institution.

Tehanetorens (1984). Cuentos de los Indios Iroqueses [Iroquois Indian Tales]. Trans. José J. Fuente del Pilar. Madrid, Miraguano Ediciones.

Thornton, Russell (1998). "Institutional and Intellectual Histories of Native American Studies." In R. Thornton, ed. Studying Native American: Problems and Prospects. Madison, The University of Wisconsin Press.

Venuti, Lawrence (1998). The Scandals of Translation: Towards an Ethics of Difference. London, Routledge.

Venuti,Lawrence (2008). "Translation,Interpretation, Canon Formation." In A. Lianeri and V. Zajko, eds. Translation and the Classic: Identity as Change in the History of Culture. Oxford, Oxford University Press.

Wallis, Velma (1997a). Las dos ancianas [The Two Old Women]. Trans. Javier Alfaya. Barcelona, Ediciones B.

Wallis, Velma (1997b). Tras el sol [After the Sun]. Trans. Carmen Netzel. Barcelona, Ediciones B.

Watts, Richard (2000). "Translating Culture: Reading the Paratexts of Aimé Césaire's Cahier d'un retour au pays natal." TTR, 13, 2, pp.2945.

Young Bear, Ray A. (1988). Restos de la primera tierra [Remainders of the First Earth]. Trans. Sofía C. Noguera. Palma de Mallorca, José J. de Olañeta.

Zitkala-Ša (1994). Cuentos y Leyendas de los Indios Sioux [Tales and Legends of the Sioux Indians]. Trans. Julio Velasco. Madrid, Miraguano Ediciones.

Zitkala-Ša (2011). Recuerdos de una india sioux [Memories of a Sioux Indian Woman]. Trans. Carlos Ezquerra. Barcelona, Erasmus Ediciones.

Isis Herrero López

Independent scholar herreroisis@hotmail.com 